\title{
ANALISA BIAYA RELEVAN UNTUK PENGAMBILAN KEPUTUSAN JANGKA PENDEK PADA PERUSAHAAN KECAP CAP "BAKSO SATE" PURWOKERTO
}

\author{
Ika Neni Kristanti, SE, M.Sc.
}

\begin{abstract}
ION
ABSTRACTION

This study aims to analyze the costs relevant to decision making soy products continue the company's plastic packaging ketchup cap "BAKSO satay" Purwokerto

The study drew on data in 2010 who suffered losses. Loss was due to higher production costs due to: rising gas prices and soaring oil prices, labor costs need to be given a salary increase and the costs of medical care from year to year increases, the engine was getting old so the ability of the operation is reduced and weakening market demand for soy products plastic packaging. From the results of the study concluded that the company should continue the plastic packaging for soy products if the company will add a stop loss is greater. This can be evidenced by the company discontinue the product if it will experience a loss of Rp. 34.092 million, whereas if you continue to lose Rp. 12.6898 million, and the difference is Rp.21,402,200, -

This research method is by way of: interviews, observation, documentation and literature study method. The main results of this study indicate that the company should continue soy plastic packaging products for reasons above.
\end{abstract}

Keywords: Decision making, relevant costs

\section{Perhitungan Biaya Relevan}

Berdasarkan masalah yang dihadapi dan keputusan yang akan diambil oleh perusahaan atau pihak manajemen atas penghentian produk kecap kemasan plastik, maka berikut ini penulis mencoba menganalisa terhadap keputusan yang akan diambil yaitu mengadakan analiasa biaya relevan terhadap pengambilan keputusan meneruskan atau menghentikan produk kecap kemasan plastik.

Dengan mengadakan analisa, penulis ingin mengetahui sejauh mana pengaruh yang akan ditimbulkan atas keputusan yang akan diambil. Selain terhambatnya proses produksi terhadap produk kecap kemasan plastik dan dampak selanjutnya yang akan timbul. Sehingga nantinya diharapkan akan tercipta suatu keputusan yang tepat dan menguntungkan sehubungan dengan pilihan salah satu alternatif keputusan dari berbagai keputusan yang ada.

Adapun dalam analisa ini alternatif yang disajikan adalah antara menghentikan atau meneruskan produk kecap kemasan plastik, dimana produk ini tidak memberikan keuntungan secara riil. Komponen biaya produksi dan biaya operasi yang dianalisa adalah:

a. Biaya bahan baku dan biaya bahan pembantu

b. Biaya tenaga kerja

c. Biaya kesejahteraan pegawai 
d. Biaya listrik dan air

e. Biaya penyusutan aktiva tetap

f. Biaya administrasi dan umum

g. Biaya penjualan

h. Biaya bunga

Dari kedelapan komponen biaya produksi kecap kemasan plastik tersebut diatas selanjutnya diadakan analisa sebagai berikut:

\section{Biaya bahan baku dan biaya bahan pembantu}

Bahan baku disini adalah bahan dasar untuk membuat kecap kemasan plastik yang terbuat dari kedelai, dan lain sebagainya. Sedangkan yang dimaksud bahan pembantu adalah bahan yang dipergunakan untuk menghasilkan kecap yang siap untuk dipasarkan.

Perusahaan kecap cap "BAKSO SATE" tidak membedakan biaya bahan baku dengan bahan pembantu, semuanya dianggap satu. Berdasarkan tingkah lakunya biaya tersebut semua dimasukan kedalam biaya variabel, karena besarnya biaya tersebut berfluktuasi seiring dengan pemakian bahan baku. Semakin banyak volume produksi dan besar bentuknya, semakin banyak pula bahan baku yang digunakan dan otomatis biaya semakin besar pula. Tetapi hal ini berpegang pada asumsi harga bahan baku relatif stabil.

Dalam hubungannyaa dengan pemilihan anatara menghentikan atau meneruskan produksi kecap kemasan plastik, jumlah pengeluaran untuk biaya ini adalah berbeda dalam dua alternative, sehingga biaya ini merupakan biaya yang terhindarkan.

\section{Biaya tenaga kerja}

Biaya tenaga kerja yang bersifat tetap ini adalah gaji atau upah yang harus dikeluarkan dalam perusahaan berproduksi. Tetapi bila perusahaan hendak menghentikan produksinya (kecap kemasan plastik), maka dari biaya ini masih haarus dikeluarkan. Hal ini disebabkan walaupun perusahaan ini tidak memproduksi kecap kemasan plastik, akan tetap mengeluarkan biaya gaji untuk membayar para staf (pegawai) dan direkturnya, karena aktivitas produksi produk yang lain tetap berlangsung. Sedangkan seandainya meneruskan produksi kecap kemasan plastik, maka ada pegawai yang diberi tanggung jawab dan tambahan beban demi berlangsungnya produksi kecap kemasan plastik, sehingga harus ada tambahan gaji tetap kepada pegawai tersebut.

Misalnya semula pegawai biasa, setelah kecap kemasan plastik diproduksi, pegawai tersebut diangkat menjadi manjer sub unit produk kecap kemasan plastik.

Tambahan biaya inilah yang relevan terhadap pengambilan keputusan antara dua laternatif pilihan menghentikan tau meneruskan produk kecap kemasan plastik, karena tambahan biaya ini membedakan kedua alternatif pilihan tersebut. Untuk lebih jelasnya dapat disimak dalam perhitungan dibawah ini yang diambil dari data perusahaan:

Total biaya tetap (gaji/upah)..........................Rp.5.202.169,50

Biaya gaji dan upah yang harus dikeluarkan bila produksi

kecap kemasan plastik dihentikan........................ Rp.9.036.000 
Biaya tetap (gaji/upah) terhindar bila produksi

kecap kemasan plastik dihentikan (relevan) .(Rp.3.833.830,5)

Biaya tenaga kerja yang bersifat variabel adalah uang lembur karyawan yang bekerja diluar jam kerja karyawan yang bekerja yang telah ditentukan. Sedangkan pemberian insentif dan biaya representatif didasarkan pada kehadiran karyawan dan adanya prestasi-prestasi yang dicapai oleh karyawan berdasarkan penilian atasannya.

Menurut bagian produksi dan bagian personalia, didapat keterangan bahwa penghentian produk kecap kemasan plastik tidak akan menyebabkan adanya lembur, karena akan secara langsung pekerjaan tersebut berhenti.

Untuk pemberian intensif dan representatif walaupun ada tetapi dianggap tidak ada, karena sulit ditelusuri.Jadi dalam dua alternatif menghentikan atau meneruskan produksi kecap kemasan plastik, biaya ini merupakan biaya terhindarkan dan relevan untuk pengambilan keputusan tersebut.

\section{Biaya kesejahteraan pegawai}

Untuk biaya kesejahteraan pegawai akan tetap dikeluarkan walaupun perusahaan menghentikan produksi kecap kemasan plastik, hal ini dikarenakan para pegawai manajernya akan tetap bekerja meskipun tidak akan lagi produktif. Jadi biaya ini termasuk dalam hal-hal yang melekat dengan produk kecap kemasan plastik dan perlu dipertimbangkan dalam menghentikan produk tersebut.

Sedangkan bila perusahaan tetap memproduksi kecap kemasan plastik, pengeluaran biaya ini lebih besar. Agar lebih jelasnya perhitungan biaya tersebut adalah :

Total biaya tetap kesejahteraan pegawai.......................(Rp.802.280)

Biaya tetap kesejahteraan pegawai yang harus dikeluarkan

bila produksi kecap kemasan plastik dihentikan................. Rp5.052.000

Biaya tetap kesejahteraan pegawai yang terhindarkan

bila produksi kecap kemasan plastik dihentikan (relevan)......(Rp.5.854.280)

Biaya kesejahteraan pegawai yang bersifat variabel meliputi biaya tunjungan natura, pakian dinas dan lain-lainya yang bersifat variabel.

Dalam alternatif menghentikan atau meneruskan produk kecap kemasan plastik jumlah pengeluaran untuk biaya ini adalah berbeda.Bila produksi kecap kemasan plastik ini diteruskan, maka biaya ini dikeluarkan.Tetapi bila menghentikan produksi kecap kemasan plastik, maka biaya ini tidak menjadi beban.Jadi biaya kesejahteraan pegawai yang bersifat variabel ini merupakan biaya yang tak terhindarkan dan relevan untuk dipertimbangkan dalam pengambilan keputusan menghentikan atau meneruskan produksi kecap kemasan plastik. 


\section{Biaya listrik dan air}

Biaya listrik dan air yang bersifat tetap merupakaan biaya yang harus dikeluarkan dalam hal perusahaan memproduksi kecap kemasan plastik, maka seperti keperluan listrik untuk penerangan dan pemabangkit tenaga mesin dalam batas normal kerja. Dalam hal perusahaan menghentikan produksi kecap kemasan plastik, biaya tetap yang tetap dikeluarkan oleh perusahaan dianggap tidak ada karena sulit untuk ditelusuri.

Sehingga dalam alternatif pilihan menghentikan atau meneruskan produksi kecap kemasan plastik, biaya listrik yang bersifat tetap ini adalah relevan untuk dipertimbangkan, karena jumlahnya berbeda.Bila memproduksi kecap kemasan plastik biaya tetap ini harus dikeluarkan, sebaliknya bila tidak memproduksi kecap kemasan plastik, maka perusahaan tidak mengeluarkan biaya tetap ini.

Biaya listrik dan air yang bersifat variabel merupakan biaya yang relevan untuk dipertimbangkan dalam pengambilan keputusan menghentikan atau meneruskan produksi kecap kemasan plastik, karena jumlahnya berbeda.

Bila memproduksi, kemungkinan mengeluarkan biaya ini, seperti tenaga listrik untuk lembur.Tetapi bila menghentikan produksi kecap kemasan plastik, maka tidak mengeluarkan biaya ini.

\section{Biaya penyusutan aktiva tetap}

Menurut tingkah lakunya biaya ini termasuk biaya tetap. Biaya penyusutan yang bersifat tetap ini adalah alokasi secara periodic dan sistimatis dari bagunana, mesin, alat perlengkapan, instalasi listrik dan air, kendaraan, inventaris dan harta lain yang dimiliki perusahaan.

Perusahaan kecap cap "BAKSO SATE” menghitung beban penyusutan dengan prosentase tetap dari nilai perolehannya yang ditetapkan berdasarkan taksiran umur ekonomisnya.

Bila penyusutan ini merupakan sunk cost (biaya masa lalu) yang tidak berbeda dalam alternatif menghentikan atau meneruskan produksi kecap kemasan plastik, karena ini adalah jumlahnya sama, sehingga bukan merupakan biaya relevan atau yang sesuai untuk diperhitungkan. Dengan asumsi bahwa semua harta yang disusutkan tidak dijual bila produksi kecap kemasan plastik dihentikan.

\section{Biaya administrasi dan umum}

Dalam perusahaan memproduksi kecap kemasan plastik, biaya tetap ini harus dikeluarkan.Sedangkan bila menghentikan produksi kecap kemasan plastik, maka harus dikeluarkan hanya sebagian dari biaya tetap tersebut, yaitu biaya administrasi dan umum yang tidak dapat dihindari keluarnya, walaupun kenyataannya perusahaan sudah menghentikan produksi kecap kemasan plastik.Hal ini karena masih ada produk-produk lain yang diproduksi.Kalau kecap kemasan plastik diproduksi, biaya ini bisa dibebankan pada biaya operasi kecap kemasan plastik sebesar beberapa persen sesuai kebijakan alokasinya. Misalnya biaya sumbangan sebesar Rp. 3.750 .000 bisa dibebankan pada : 
Biaya operasi produk kecap botol besar..................1.425.000

Biaya operasi produk kecap botol kecil......................1.200.000

Biaya operasi produk kecap kemasan plastik...............1.125.000

Tetapi bila produksi kecap kemasan plastik dihentikan, biaya sumbungan bisa ditekan menjadi Rp. 3.650.000 dan alokasinya bisa menjadi.

Biaya operasi produk kecap botol besar.......................1.475.000

Biaya oprasi produk kecap botol kecil...................1.175.000

Seperti contoh diatas, maka bila menghentikan produk kecap kemasan plastik, biaya administrasi dan umum yang terbeban pada produk nkecap kemasan botol besar, dan botol kecil menjadi beban tetap produk klkecap kemasan plastik walaupun produk kecap kemasan plastik dihentikan.Jadi dari contoh diatas yang terbeban pada produk kecap kemasan plasik adalah sebesar :

Kecap botol besar.........................(1.475.000 + 1.175.000)

Kecap botol kecil........................... (1.425.000+1.200.000)

Yang terbeban pada kemasan plastik........................25.000

Biaya yang seperti ini yang masih melekat pada kecap kemasan plastik meskipun sudah dihentikan. Berikut ini dicantumkan perhitungan biaya administrasi dan umum dalam memproduksi kecap kemasan plastik yang masih harus dikeluarkan bila produksi dihentikan, yaitu :

Total biaya tetap........................................ (Rp. 755.496)

Biaya tetap yang harus dikeluarkan bila produksi

kecap kemasan plastik dihentikan........................Rp.1.248.000

Biaya terhindarkan bila produksi

kecap kemasan plastik dihentikan........................(Rp.2.003.496)

Jadi dalam pemilihan antara menghentikan atau meneruskan produk kecap kemasan plastik, biaya sebesar(Rp.2.003.496) merupakan biaya relevan, karena dapat dihindarkan.

\section{Biaya penjualan}

Biaya penjualan yang bersifat tetap yanga ada dalam perusahaan kecap cap "BAKSO SATE" adalah biaya sehubungan dengan promosi, seperti yang sering dilakukan selama ini, yaitu dengan member potongan harga pada pada tingkat pembelian tertentu, biaya angkut, biaya pembungkusan, biaya pengiriman dan lain-lain.

Seperti halnya dengan biaya administrasi dan umum, bila memproduksi kecap kemasan plastik, biaya ini tetap ini harus dikeluarkan. Sedangkan bila menghentikan produksi kecap kemasan plastiknya, masih tetap mengeluarkan sebagian biaya ini, yaitu biaya tetap yang tidak dapat dihindari keluarnya sehubungan dengan masih diproduksinya produk lain. Perhitungan biayabiaya tersebut adalah :

Total biaya tetap.

Rp.47.805.000

Biaya tetap yang harus dikeluarkan bila produk

kecap kemasan plastik dihentikan........................ Rp.1.500.000

Biaya terhindarkan bila kecap kemasan plastik

dihentikan............................................Rp.46.305.000 
Jadi biaya sejumlah Rp.46.305.000inilah yang relevan terhadap pengambilan keputusan menghentikan atau meneruskan produksi kecap kemasan plastik, karena jumlahnya berbeda diantara dua alternatif.

\section{Biaya bunga}

Biaya menurut tingkah lakunya seluruhnya bersifat tetap.Dengan asumsi bahwa bila menghentikan produksi kecap kemasan plastik semua pinjaman-pinjaman untuk produksi kecap kemasan plastik dikembalikan, sehinggga tidak ada bumnga yang membebani. Maka biaya bunga ini dapat terhindarkan, karena berbeda diantara alternatif pilihan atau relevan untuk dipertimbangkan

TABEL 1

PENGUSAHA KECAP CAP "BAKSO SATE" PURWOKERTO

BIAYA GAJI DAN UPAH BULANAN UNTUK PRODUK KEMASAN PLASTIK

\begin{tabular}{|l|r|c|r|r|}
\hline \multicolumn{1}{|c|}{ BULAN } & $\begin{array}{c}\text { GAJI/UPAH } \\
(\mathrm{Y})\end{array}$ & $\begin{array}{c}\text { VOLUME } \\
\text { PRODUKSI } \\
(\mathrm{X})\end{array}$ & $\mathrm{XY}$ & $\mathrm{X}^{2}$ \\
\hline Januari & 3.135 .000 & 26.860 & 84.689 .580 .000 & 721.459 .600 \\
Pebruari & 3.553 .000 & 29.060 & 103.250 .180 .000 & 844.483 .600 \\
Maret & 3.224 .500 & 27.660 & 89.742 .870 .000 & 765.075 .600 \\
April & 3.128 .000 & 26.460 & 82.766 .880 .000 & 700.131 .600 \\
Mei & 3.116 .000 & 26.300 & 81.974 .470 .000 & 691.690 .000 \\
Juni & 3.072 .000 & 24.660 & 75.755 .520 .000 & 608.115 .600 \\
Juli & 3.102 .400 & 26.060 & 80.848 .544 .000 & 679.123 .600 \\
Agustus & 3.077 .000 & 23.880 & 73.478 .760 .000 & 570.254 .400 \\
September & 3.138 .000 & 25.460 & 79.903 .664 .000 & 648.211 .600 \\
Oktober & 3.082 .800 & 24.460 & 75.405 .288 .000 & 598.291 .600 \\
Nopember & 3.068 .800 & 23.260 & 71.380 .288 .000 & 541.027 .600 \\
Desember & 3.063 .200 & 23.080 & 70.698 .656 .000 & 532.686 .400 \\
\hline Jumlah & 37.800 .000 & 307.200 & 969.894 .700 .000 & 7.900 .551 .200 \\
\hline
\end{tabular}

Sumber data: perusahaan Kecap cap "Bakso Sate" Purwokerto.

Biaya variable $=$

$$
\begin{aligned}
\mathrm{B} & =\frac{? \sum ? ?-\sum ? \sum ?}{? \sum ?^{2}-\left(\sum ?\right)^{2}} \\
& =\frac{12 \times 969.894 .700 .000-307.200 \times 37.800 .000}{12 \times 7.900 .551 .200-(307.200)^{2}} \\
& =\text { Rp. 106,11 per volume penjualan }
\end{aligned}
$$

Biaya variable gaji/upah tahun $2010=$ Rp. 106,11 X 307.200

Biaya tetap $=$

$$
=\text { Rp. 32.597.830,50 }
$$

$$
\mathrm{a}=\frac{\sum ?-? \sum ?}{?}
$$




$$
\begin{aligned}
& =\frac{37.800 .000-106 \times 307.200}{12} \\
& =\text { Rp. 433.514,13per bulan }
\end{aligned}
$$

Biaya tetap gaji/upah tahun $2010=$ Rp. $433.514,13 \times 12$

$$
=\text { Rp. } 5 \cdot 202 \cdot 169,50
$$

TABEL 2

PENGUSAHA KECAP CAP "BAKSO SATE" PURWOKERTO

BIAYA KESEJAHTERAAN PEGAWAI BULANAN UNTUK PRODUK KECAP KEMASAN PLASTIK

\begin{tabular}{|l|c|c|c|c|}
\hline \multicolumn{1}{|c|}{ BULAN } & $\begin{array}{c}\text { KESEJT.PEG } \\
(\mathrm{Y})\end{array}$ & $\begin{array}{c}\text { VOLUME } \\
\text { PRODUKSI } \\
(\mathrm{X})\end{array}$ & $\mathrm{XY}$ & $\mathrm{X}^{2}$ \\
\hline Januari & 1.543 .400 & 26.860 & 41.455 .724 .000 & 721.459 .600 \\
Pebruari & 1.727 .600 & 29.060 & 50.204 .056 .000 & 844.483 .600 \\
Maret & 1.569 .400 & 27.660 & 43.405 .604 .000 & 765.075 .600 \\
April & 1.511 .400 & 26.460 & 39.991 .644 .000 & 700.131 .600 \\
Mei & 1.506 .400 & 26.300 & 39.618 .320 .000 & 691.690 .000 \\
Juni & 1.470 .600 & 24.660 & 36.264 .996 .000 & 608.115 .600 \\
Juli & 1.493 .000 & 26.060 & 38.907 .580 .000 & 679.123 .600 \\
Agustus & 1.475 .200 & 23.880 & 35.227 .776 .000 & 570.254 .400 \\
September & 1.518 .800 & 25.460 & 38.668 .648 .000 & 648.211 .600 \\
Oktober & 1.483 .600 & 24.460 & 36.288 .856 .000 & 598.291 .600 \\
Nopember & 1.458 .800 & 23.260 & 33.931 .688 .000 & 541.027 .600 \\
Desember & 1.455 .200 & 23.080 & 33.586 .016 .000 & 532.686 .400 \\
\hline Jumlah & 18.213 .400 & 307.200 & 467.554 .908 .000 & 7.900 .551 .200 \\
\hline
\end{tabular}

Sumber data: perusahaan Kecap cap "Bakso Sate" Purwokerto.

Biaya variable $=$

$$
\begin{aligned}
\mathrm{b} & =\frac{? \sum ? ?-\sum ? \sum ?}{? \sum ?^{2}-\left(\sum ?\right)^{2}} \\
& =\frac{12 \times 467.554 .908 .000-307.200 \times 18.213 .400}{12 \times 7.900 .551 .200-(307.200)^{2}} \\
& =\text { Rp. } 61,90 \text { per volume penjualan }
\end{aligned}
$$

Biaya variabel kesej.pegawai tahun $2010=$ Rp. $61,90 \times 307.200$

$$
=\text { Rp. } 19.015 .680
$$

Biaya tetap $=$

$$
\begin{aligned}
\mathrm{a} & =\frac{\sum ?-? \sum ?}{?} \\
& =\frac{18.213 .400 ? 36 \times 307.200}{12} \\
& =(\text { Rp. } 66.856,67) \text { per bulan }
\end{aligned}
$$

Biaya tetap kesej.pegawai tahun $2010=($ Rp. 66.856,67 $) \times 12=($ Rp. 802.280 $)$ 
TABEL 3

PENGUSAHA KECAP CAP "BAKSO SATE" PURWOKERTO BIAYA LISTRIK DAN AIR BULANAN UNTUK PRODUK KECAP KEMASAN PLASTIK

\begin{tabular}{|l|c|c|c|c|}
\hline \multicolumn{1}{|c|}{ BULAN } & $\begin{array}{c}\text { LISTRIK } \\
\text { DAN AIR } \\
(\mathrm{Y})\end{array}$ & $\begin{array}{c}\text { VOLUME } \\
\text { PRODUKSI } \\
(\mathrm{X})\end{array}$ & $\mathrm{XY}$ & $\mathrm{X}^{2}$ \\
\hline Januari & 1.336 .400 & 26.860 & 36.701 .504 .000 & 721.459 .600 \\
Pebruari & 1.553 .600 & 29.060 & 44.566 .416 .000 & 844.483 .600 \\
Maret & 1.383 .800 & 27.660 & 38.275 .908 .000 & 765.075 .600 \\
April & 1.365 .800 & 26.460 & 36.239 .078 .000 & 700.131 .600 \\
Mei & 1.363 .000 & 26.300 & 35.846 .900 .000 & 691.690 .000 \\
Juni & 1.347 .800 & 24.660 & 33.236 .748 .000 & 608.115 .600 \\
Juli & 1.359 .600 & 26.060 & 35.431 .176 .000 & 679.123 .600 \\
Agustus & 1.327 .600 & 23.880 & 31.703 .088 .000 & 570.254 .400 \\
September & 1.355 .800 & 25.460 & 34.518 .668 .000 & 648.211 .600 \\
Oktober & 1.340 .600 & 24.460 & 32.791 .076 .000 & 598.291 .600 \\
Nopember & 1.307 .800 & 23.260 & 30.419 .428 .000 & 541.027 .600 \\
Desember & 1.301 .000 & 23.080 & 30.027 .080 .000 & 532.686 .400 \\
\hline Jumlah & 16.352 .800 & 307.200 & 419.657 .060 .000 & 7.900 .551 .200 \\
\hline
\end{tabular}

Sumber data: perusahaan Kecap cap "Bakso Sate" Purwokerto.

Biaya variable $=$

$$
\begin{aligned}
& \mathrm{b}=\frac{? \sum ? ?-\sum ? \sum ?}{? \sum ?^{2}-\left(\sum ?\right)^{2}} \\
& =\frac{12 \times 419.657 .060 .000 ? 307.200 ? 16.352 .800}{12 \times 7.900 .551 .200-(307.200)^{2}} \\
& =\text { Rp. 49,13per volume penjualan }
\end{aligned}
$$

Biaya variabel listrik dan air tahun $2010=$ Rp. 49,13 X 307.200

$$
=\text { Rp. } 15.092 .736
$$

Biaya tetap $=$

$$
\begin{aligned}
\mathrm{a} & =\frac{\sum ?-? \sum ?}{? \cdot{ }^{2} 2.800-49,13 \times 307.200} \\
& =\frac{16.32}{12} \\
& =\text { Rp. } 105.055,33 \text { per bulan }
\end{aligned}
$$

Biaya tetap lisrik dan air tahun $2010=\mathrm{Rp} 105.055,33 \times 12$

$$
=\text { Rp. } 1.260 .064
$$


TABEL 4

PENGUSAHA KECAP CAP "BAKSO SATE” PURWOKERTO

BIAYA PENYUSUTAN AKTIVA TETAP BULANAN UNTUK PRODUK KECAP KEMASAN PLASTIK

\begin{tabular}{|l|c|c|c|c|}
\hline \multicolumn{1}{|c|}{ BULAN } & $\begin{array}{c}\text { PENYUSUTAN } \\
(\mathrm{Y})\end{array}$ & $\begin{array}{c}\text { VOLUME } \\
\text { PRODUKSI } \\
(\mathrm{X})\end{array}$ & $\mathrm{XY}$ & $\mathrm{X}^{2}$ \\
\hline Januari & 1.438 .000 & 26.860 & 38.624 .680 .000 & 721.459 .600 \\
Pebruari & 1.438 .000 & 29.060 & 41.788 .280 .000 & 844.483 .600 \\
Maret & 1.438 .000 & 27.660 & 39.775 .080 .000 & 765.075 .600 \\
April & 1.438 .000 & 26.460 & 38.049 .480 .000 & 700.131 .600 \\
Mei & 1.438 .000 & 26.300 & 37.819 .400 .000 & 691.690 .000 \\
Juni & 1.438 .000 & 24.660 & 35.461 .080 .000 & 608.115 .600 \\
Juli & 1.438 .000 & 26.060 & 37.474 .280 .000 & 679.123 .600 \\
Agustus & 1.438 .000 & 23.880 & 34.339 .440 .000 & 570.254 .400 \\
September & 1.438 .000 & 25.460 & 36.611 .480 .000 & 648.211 .600 \\
Oktober & 1.438 .000 & 24.460 & 35.173 .480 .000 & 598.291 .600 \\
Nopember & 1.438 .000 & 23.260 & 33.447 .880 .000 & 541.027 .600 \\
Desember & 1.438 .000 & 23.080 & 33.189 .040 .000 & 532.686 .400 \\
\hline Jumlah & 17.256 .000 & 307.200 & 441.753 .600 .000 & 7.900 .551 .200 \\
\hline
\end{tabular}

Sumber data: perusahaan Kecap cap "Bakso Sate" Purwokerto.

Biaya variable $=$

$$
\begin{aligned}
& \mathrm{b}=\frac{? \sum ? ?-\sum ? \sum ?}{? \sum ?^{2}-\left(\sum ?\right)^{2}} \\
& =\frac{12 \times 441.753 .600 .000 ? 307.200 \times 17256.000}{12 \times 7.900 .551 .200-(307.200)^{2}} \\
& =\text { Rp. } 0 \text { per volume penjualan }
\end{aligned}
$$

Biaya variabel penyusutan aktiva tetap tahun $2010=$ Rp. 0

Biaya tetap $=$

$$
\begin{aligned}
\mathrm{a} & =\frac{\sum ?-? \sum ?}{?} \\
& =\frac{17.2 \dot{5} 6.000-0 \times 307.200}{12} \\
& =\text { Rp. 1.438.000per bulan }
\end{aligned}
$$

Biaya tetap peny. Aktiva tetap tahun $2010=$ Rp. $1.438 .000 \times 12$

$=$ Rp. 17.256 .000 
TABEL 5

PENGUSAHA KECAP CAP "BAKSO SATE" PURWOKERTO

BIAYA ADMINISTRASI DAN UMUM BULANAN UNTUK PRODUK KECAP KEMASAN PLASTIK

\begin{tabular}{|l|c|c|c|c|}
\hline \multicolumn{1}{|c|}{ BULAN } & $\begin{array}{c}\text { ADM \&UMUM } \\
(\mathrm{Y})\end{array}$ & $\begin{array}{c}\text { VOLUME } \\
\text { PRODUKSI } \\
(\mathrm{X})\end{array}$ & $\mathrm{XY}$ & $\mathrm{X}^{2}$ \\
\hline Januari & 769.400 & 26.860 & 20.666 .084 .000 & 721.459 .600 \\
Pebruari & 864.200 & 29.060 & 25.113 .652 .000 & 844.483 .600 \\
Maret & 777.800 & 27.660 & 21.513 .948 .000 & 765.075 .600 \\
April & 768.400 & 26.460 & 20.331 .864 .000 & 700.131 .600 \\
Mei & 764.800 & 26.300 & 20.114 .240 .000 & 691.690 .000 \\
Juni & 747.800 & 24.660 & 18.440 .748 .000 & 608.115 .600 \\
Juli & 759.600 & 26.060 & 19.795 .176 .000 & 679.123 .600 \\
Agustus & 733.200 & 23.880 & 17.508 .816 .000 & 570.254 .400 \\
September & 753.400 & 25.460 & 19.181 .564 .000 & 648.211 .600 \\
Oktober & 743.000 & 24.460 & 18.173 .780 .000 & 598.291 .600 \\
Nopember & 728.600 & 23.260 & 16.947 .236 .000 & 541.027 .600 \\
Desember & 720.000 & 23.080 & 16.617 .600 .000 & 532.686 .400 \\
\hline Jumlah & 9.130 .200 & 307.200 & 153.477 .120 .000 & 7.900 .551 .200 \\
\hline
\end{tabular}

Sumber data: perusahaan Kecap cap "Bakso Sate" Purwokerto.

Biaya variable $=$

$$
\begin{aligned}
\mathrm{b} & =\frac{? \sum ? ?-\sum ? \sum ?}{? \sum ?^{2}-\left(\sum ?\right)^{2}} \\
& =\frac{12 \times 153.477 .120 .000-307.200 \times 9.130 .200}{12 \times 7.900 .551 .200-(307.200)^{2}} \\
& =\text { Rp. 32,18 per volume penjualan }
\end{aligned}
$$

Biaya variabel adm. dan umum tahun $2010=$ Rp. $32,18 \times 307.200$

$$
=\text { Rp. } 9.885 .696
$$

Biaya tetap $=$

$$
\begin{aligned}
\mathrm{a} & =\frac{\sum ?-? \sum ?}{?} \\
& =\frac{9.130 .200-32,18 \times 307.200}{12} \\
& =(\text { Rp.62.958) per bulan }
\end{aligned}
$$

Biaya tetap adm. dan umum tahun $2010=($ Rp.62.958) $\times 12$

$$
=(\operatorname{Rp} .755 .496)
$$


TABEL 6

PENGUSAHA KECAP CAP "BAKSO SATE" PURWOKERTO

BIAYA BUNGA BULANAN UNTUK PRODUK KECAP KEMASAN PLASTIK

\begin{tabular}{|l|c|c|r|r|}
\hline \multicolumn{1}{|c|}{ BULAN } & B.BUNGA & $\begin{array}{c}\text { VOLIME } \\
\text { PRODUKSI } \\
(\mathrm{X})\end{array}$ & $\mathrm{XY}$ & $\mathrm{X}^{2}$ \\
\hline Januari & 499.600 & 26.860 & 13.419 .2506 .000 & 721.459 .600 \\
Pebruari & 499.600 & 29.060 & 14.518 .376 .000 & 844.483 .600 \\
Maret & 499.600 & 27.660 & 13.818 .936 .000 & 765.075 .600 \\
April & 499.600 & 26.460 & 13.219 .416 .000 & 700.131 .600 \\
Mei & 499.600 & 26.300 & 13.139 .480 .000 & 691.690 .000 \\
Juni & 499.600 & 24.660 & 12.320 .136 .000 & 608.115 .600 \\
Juli & 499.600 & 26.060 & 13.019 .576 .000 & 679.123 .600 \\
Agustus & 499.600 & 23.880 & 11.930 .448 .000 & 570.254 .400 \\
September & 499.600 & 25.460 & 12.719 .816 .000 & 648.211 .600 \\
Oktober & 499.600 & 24.460 & 12.220 .216 .000 & 598.291 .600 \\
Nopember & 499.600 & 23.260 & 11.620 .696 .000 & 541.027 .600 \\
Desember & 499.600 & 23.080 & 11.530 .768 .000 & 532.686 .400 \\
\hline Jumlah & 5.995 .200 & 307.200 & 153.477 .120 .000 & 7.900 .551 .200 \\
\hline
\end{tabular}

Sumber data: perusahaan Kecap cap "Bakso Sate” Purwokerto.

Biaya variable $=$

$$
\begin{aligned}
\mathrm{b} & =\frac{? \sum ? ?-\sum ? \sum ?}{? \sum ?^{2}-\left(\sum ?\right)^{2}} \\
& =\frac{12 \times 153.477 .120 .000-307.200 ? 5.995 .200}{127.900 .551 .200 \times-(307.200)^{2}} \\
& =\text { Rp. } 0 \text { per volume penjualan }
\end{aligned}
$$

Biaya variabel bunga tahun $2010=$ Rp. $0 \times 307.200$

$$
=\text { Rp. } 0
$$

Biaya tetap $=$

$$
\begin{aligned}
\mathrm{a} & =\frac{\sum ?-? \sum ?}{?} \\
& =\frac{5.995 .200-0 \times 307.200}{12} \\
& =\text { Rp. } 499.600 \text { per bulan }
\end{aligned}
$$

Biaya tetap bunga tahun $2010=\mathrm{Rp} .499 .600 \times 12$

$$
=\text { Rp. 5.995.200 }
$$


TABEL 7

PENGUSAHA KECAP CAP "BAKSO SATE" PURWOKERTO

BIAYA BUNGA PENJUALAN UNTUK PRODUK KECAP KEMASAN PLASTIK

\begin{tabular}{|l|r|c|l|c|}
\hline \multicolumn{1}{|c|}{ BULAN } & $\begin{array}{c}\text { B.PENJUALAN } \\
(\mathrm{Y})\end{array}$ & $\begin{array}{c}\text { PENJUALAN } \\
(\mathrm{X})\end{array}$ & \multicolumn{1}{c|}{$\mathrm{XY}$} & $\mathrm{X}^{2}$ \\
\hline Januari & 939.400 & 26.860 & 25.232 .284 .000 & 721.459 .600 \\
Pebruari & 780.000 & 29.060 & 224.666 .800 .000 & 844.483 .600 \\
Maret & 600.800 & 27.660 & $16.618 . .128 .000$ & 765.075 .600 \\
April & 802.800 & 26.460 & 21.242 .088 .000 & 700.131 .600 \\
Mei & 1.100 .000 & 26.300 & 28.930 .000 .000 & 691.690 .000 \\
Juni & 900.000 & 24.660 & 22.194 .000 .000 & 608.115 .600 \\
Juli & 912.000 & 26.060 & 23.766 .720 .000 & 679.123 .600 \\
Agustus & 1.140 .000 & 23.880 & 27.223 .200 .000 & 570.254 .400 \\
September & 940.000 & 25.460 & 23.932 .400 .000 & 648.211 .600 \\
Oktober & 1.004 .600 & 24.460 & 24.516 .572 .000 & 598.291 .600 \\
Nopember & 904.400 & 23.260 & 21.036 .344 .000 & 541.027 .600 \\
Desember & 1.301 .000 & 23.080 & 30.027 .080 .000 & 532.686 .400 \\
\hline Jumlah & 11.325 .000 & 307.200 & 287.441 .560 .000 & 7.900 .551 .200 \\
\hline
\end{tabular}

Sumber data: perusahaan Kecap cap "Bakso Sate" Purwokerto.

Biaya variable $=$

$$
\begin{aligned}
\mathrm{b}= & \frac{? \sum ? ?-\sum ? \sum ?}{? \sum ?^{2}-\left(\sum ?\right)^{2}} \\
& =\frac{12 ? 287.441 .560 .000-307.200 ? 11.325 .000}{12 ? 7.900 .551 .200-(307.200)^{2}} \\
& =(\text { Rp.118,75) per volume penjualan }
\end{aligned}
$$

Biaya variabel bunga tahun $2010=(\mathrm{Rp} .118,75) \times 307.200$

Biaya tetap $=$

$$
=(\operatorname{Rp} .36 .480 .000)
$$

$$
\begin{aligned}
\mathrm{a}= & \frac{\sum ?-? \sum ?}{?} \\
& =\frac{11.325 .000-1.107,82 \times 307.200}{12} \\
& =3.983 .750 \text { per bulan }
\end{aligned}
$$

Biaya tetap bunga tahun $2010=$ Rp. $3.983 .750 \times 12$

$$
=\text { Rp. } 47.805 .000
$$


TABEL 8

PEMISAHAN BIAYA VARIABEL DENGAN BIAYA TETAP DAN PEMISAHAN BIAYA TERHINDAR - BIAYA TAK TERHINDAR PADA PRODUK KECAP KEMASAN PLASTIK

(DATA TAHUN 2010)

\begin{tabular}{|c|c|c|c|c|c|c|}
\hline URAIAN BIAYA & $\begin{array}{l}(\mathrm{a}+\mathrm{b}) \\
\text { TOTAL } \\
\text { BIAYA }\end{array}$ & $\begin{array}{c}(\text { a }) \\
\text { BI. VARIABEL }\end{array}$ & $\begin{array}{c}(\mathrm{b}) \\
\text { BI TETAP }\end{array}$ & $\begin{array}{c}(\mathrm{c}) \\
\text { B. TAK } \\
\text { TERHINDAR }\end{array}$ & $\begin{array}{c}(b-c) \\
\text { BI TETAP } \\
\text { TERHINDAR }\end{array}$ & $\begin{array}{c}\text { ( a )+( b-c) } \\
\text { TOTAL } \\
\text { BIAYA } \\
\text { RELEVAN }\end{array}$ \\
\hline $\begin{array}{l}\text { B baku \& b } \\
\text { pembantu }\end{array}$ & 47.186 .800 & 47.186 .800 & - & - & - & 47.186 .800 \\
\hline Gaji/upah & 37.800 .000 & $32.597 .830,5$ & $5.202 .169,50$ & 9.036 .000 & $(3.833 .830,5)$ & 28.764 .000 \\
\hline $\begin{array}{l}\text { Kesejahteraa } \\
\mathrm{n} \text { pegawai }\end{array}$ & 18.213 .400 & 19.015 .680 & $(802.280)$ & 5.052 .000 & $(5.854 .280)$ & 24.869 .960 \\
\hline $\begin{array}{l}\text { Listrik dan } \\
\text { air }\end{array}$ & 16.352 .800 & 15.092 .736 & 1.260 .064 & - & 1.260 .064 & 16.352 .800 \\
\hline $\begin{array}{l}\text { Peny. Aktiva } \\
\text { tetap }\end{array}$ & 17.256 .000 & - & 17.256 .000 & 17.256 .000 & - & - \\
\hline Bi. Penjualan & 11.325 .000 & $(36.480 .000)$ & 47.805 .000 & 1.500 .000 & 46.305 .000 & 9.825 .000 \\
\hline umum & 9.130 .200 & 9.885 .696 & $(755.496)$ & 1.248 .000 & $(2.003 .496)$ & 7.882 .200 \\
\hline Bi. Bunga & 5.993 .200 & - & 5.995 .200 & - & 5.995 .200 & 5.995 .200 \\
\hline Jumlah & 163.257 .400 & $87.298 .742,5$ & $75.960 .657,5$ & 34.092 .000 & $41.868 .657,5$ & 140.875 .960 \\
\hline
\end{tabular}

Sumber data : Perusahaan Kecap cap “BAKSO SATE” Purwokerto 
TABEL 9

PERBANDINGAN KERUGIAN

ANTARA KASUS MENGHENTIKAN ATAU MENERUSKAN

PRODUK KECAP KEMASAN PLASTIK

\begin{tabular}{|l|c|l|}
\hline URAIAN & $\begin{array}{l}\text { Menghentikan produk } \\
\text { kecap kemasan platik }\end{array}$ & $\begin{array}{l}\text { Meneruskan produk kecap } \\
\text { kemasan plastik }\end{array}$ \\
\hline PENJUALAN & - & 150.345 .000 \\
$\begin{array}{l}\text { Biaya variabel } \\
\text { Biaya tetap }\end{array}$ & 34.092 .000 & $\begin{array}{l}\text { 87.298.742,5 } \\
75.960 .657,5\end{array}$ \\
\hline Total biaya & - & 163.259 .400 \\
\hline Kerugian & 34.092 .000 & 12.914 .400 \\
\hline
\end{tabular}

Sumber data : Perusahaan Kecap cap “BAKSO SATE” Purwokerto

\section{KESIMPULAN}

Dari hasil penelitian yang didapat diperusahaan kecap cap "BAKSO SATE" Purwokerto, maka dapat ditarik kesimpulan sebagai berikut:

1. Dengan menggunakan Analisis biaya relevan untuk menganalisa masalah yang tengah terjadi pada perusahaan kecap cap "BAKSO SATE" Purwokerto maka didapatkan hasil yaitu.

\begin{tabular}{|c|c|c|}
\hline $\begin{array}{l}\text { Meneruskan kecap } \\
\text { produk kenghentikan } \\
\text { kemasan plastik }\end{array}$ & $\begin{array}{l}\text { Mengak kecap } \\
\text { produk } \\
\text { kemasan plastik }\end{array}$ & Selisih \\
\hline Rp.12.689.800,- & Rp.34.092.000,- & $\begin{array}{c}\text { Rp.21.402.2 } \\
00,-\end{array}$ \\
\hline
\end{tabular}

Dari tabel diatas maka dapat disimpulkan, jika perusahaan menghentikan produk kecap kemasan plastik, maka kerugian yang akan diderita akan menjadi lebih besar. Bila semula pada saat memproduksi kecap kemasan plastik perusahaan mengalami kerugian sebesar Rp.12.689.800, tetapi setelah produksi dihentikan ternyata perusahaan harus menanggung beban yang tidak dapat dihindarkan, dimana besarnya melebihi kerugian pada saat memproduksi, yaitu sebesar Rp.34.092.000.

Jadi adanya tambahan kerugian akibat dari menghentikan produk kecap kemasan plastik adalah sebesar Rp.21.402.200 hasil dari (Rp.34.092.000 - Rp.12.689.800). Dengan alasan tersebut maka sebaiknya perusahaan kecap cap "BAKSO SATE" Purwokerto memutuskan untuk meneruskan produk kecap kemasan plastik dengan alasan didiatas.

2. Dengan diterapkannya teknik analisa biaya relevan sebagai alat penolong dalam mempertimbangkan keputusan untuk menghentikan produk kecap kemasan plastik, dapat 
diketahui bahwa keuntungan perusahaan secara keselurhan (dalam botol besar, kecil, dan plastik) semakin menurun. Dikarenakan produk kecap kemasan plastik sebetulnya memberikan "Contribution margin". Jadi jika produk kecap kemasan plastik dihentikan, maka contribution margin tersebut akan hilang dan keuntungan menjadi turun. Dan dengan melaksanakan pemisahan biaya variabel, biaya tetap, biaya terhindar dan biaya tidak terhindar, maka dalam pengambilan keputusan manajer perusahan tidak akanmengalami keraguan, karena keputusan tersebut dapat menggambarkan keuntungan yang akan diperoleh dimasa yang akan datang disertai perhitungan dan analisannya.

\section{DAFTAR PUSTAKA}

Mulyadi. 2000. Akuntansi Biaya, Edisi 3. Yogyakarta: Penerbit BPFE UGM.

Baridwan, Zaki. 2000. Intermediate Accounting, edisi 5. Yogyakarta: Penerbit STIE YKPN.

Hartanto. 2001. Akuntansi Untuk Usahawan, Edisi kelima. Jakarta: Penerbit FE UI

Supriyono. 2000. Akuntansi Biaya, pengumpulan biaya, dan penentuan harga pokok, buku satu, Edisi satu, Cetakan empat. Yogyakarta: BPFE UGM.

Mulyadi. 2000. Akuntansi Biaya untuk Management, Edisi 4, Cetakan Kedua. Yogyakarta: BPFE. 